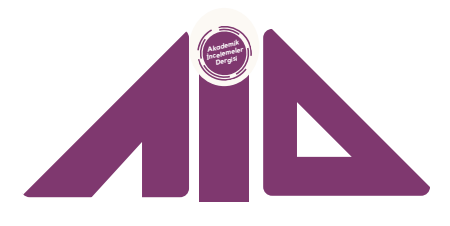

\title{
Covid-19 Sağlık Krizi Gazete Haberlerinin Salgının Seyri Kapsamında Analizi
}

\author{
Analysis of the Covid-19 Health Crisis Newspaper News in the \\ Context of the Pandemic's Course
}

\begin{abstract}
Eda TURANCI
Dr. Öğr.üyesi Hacı Bayram Veli Üniversitesi, İletișim Fakültesi, Halkla İlișkileri ve Tanıtım edaturanci@hotmail.com

https://orcid.org/0000-0002-2539-8452
\end{abstract}

\section{Araștırma \& Yayın Etiği \\ Bu makale en az iki hakem tarafindan incelenmiș, iThenticate yazılımı ile taranmıș, araștırma yayın ve etiğine aykıılık tespit edilmemiștir.}

\section{BY-NC 4.0}

Bu makale Creative Commons Attribution-NonCommercial License altında lisanslanmıștır.

This paper is licensed under a Creative Commons Attribution-NonCommercial License

\section{Research \& Publication Ethics}

This article was reviewed by at least two referees, a similarity report was obtained using iThenticate, and compliance with research/publication ethics was confirmed.

\section{Copyright $\odot$}

Sakarya Üniversitesi, Sosyal Bilimler Enstitüsü, Sakarya/TÜRKIYE

Sakarya University, Institute of Social Science, Sakarya/TURKEY

\section{Atıf/Citation}

Turancı, Eda. "Covid-19 Sağlık Krizi Gazete Haberlerinin Salgının Seyri Kapsamında Analizi". Akademik İncelemeler Dergisi 16 / 2 (Ekim 2021): 119-139. https://doi.org/10.17550/akademikincelemeler.960383

Makale Türü/Article Type: Araştırma Makalesi/Research Article

Geliş Tarihi/Date Received: 30.06.2021

Kabul Tarihi/Date Accepted: 12.10 .2021

Yayın Tarihi/Date Published: 15.10.2021

ISSN: $1306-7885$

E-ISSN: $2602-3016$

Cilt/Volume: 16 | Sayl/Issue: 2 |

Yll/Year: 2021 (Ekim/October) 


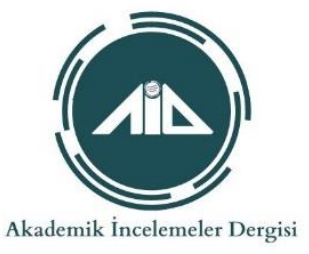

\title{
Covid-19 Sağlık Krizi Gazete Haberlerinin Salgının Seyri Kapsamında Analizi
}

\section{Öz}

Çalışmanın amacı, bir yılı aşkın süredir devam eden Covid-19 salgını ile ilgili gazete haberlerinin, salgının seyriyle bağlantılı olarak incelenmesi ve haberlerde öne çıkan konuların, çerçeveleme perspektifi bağlamında analizidir. Krizlerin kamuoyu tarafından algılanması, anlaşılması ve bilgi alışverişi sağlanması açısından medya ve özellikle haberler, etkili ve işlevsel bir role sahiptir. Küresel çapta bir kriz olan Covid19 salgını ise, uzun bir zaman dilimine yayılması, yönetilmesi ve kontrol altına alınması zor olması ve aynı zamanda bilgi ihtiyacının yoğun olduğu bir kriz olması nedeniyle iletişimin ve haberlerin öneminin daha da belirgin olduğu bir döneme ișaret etmektedir. 11 Mart 2020 tarihinden Mart 2021 tarihine kadar Hürriyet, Sabah ve Sözcü gazetelerinin birinci sayfalarından amaçlı örneklem yöntemiyle elde edilen haberler, literatürden de faydalanarak oluşturulmuş çerçeveler bağlamında içerik analizi yöntemiyle incelenmiştir. Analizler sonucunda araştırma kapsamında incelenen haberlerin en çok, "kapanma" dönemine de denk gelen Aralık ayında yer aldığı ve bunu sırasıyla "salgının ilk üç ayı" olarak görülen Nisan ve Mart aylarının izlediği, haberlerde en çok "bilgi verme" ve "tedbir-önlem-uyarı" çerçevelerine yer verildiği görülmüştür. Çalışmada, gazeteler ile ilgili haberin birinci sayfada bulunma durumu arasında, gazeteler ile haber çerçeveleri arasında ve çerçeveler ile salgının üçer aylık periyotları arasında istatistiksel anlamlı ilişki bulunduğu tespit edilmiştir. İlgili haberlerin en çok Hürriyet gazetesinde bulunduğu görülmüştür.

Anahtar Kelimeler: Halkla İlişkiler, Kriz, Covid-19, Çerçeveleme, Gazete Haberleri

\section{Analysis of the Covid-19 Health Crisis Newspaper News in the Context of the Pandemic's Course}

\begin{abstract}
The aim of the study is to analyze the newspapers news about the Covid-19 pandemic, which has been going on for more than a year, in connection with the course of the pandemic and to analyze the prominent issues in this news in the context of framing perspective. The media, and especially the news, have an effective and functional role in the perception, understanding and information exchange of crises by the public. The Covid-19 pandemic, which is a global crisis, points to a period in which the importance of communication and news is even more evident because it is a crisis that spreads over a long period of time, is difficult to manage and control, and at the same time, the need for information is intense. In the study, the news obtained from the front pages of Hürriyet, Sabah and Sözcü newspapers from March 11, 2020 to March 2021 by purposive sampling method, were analyzed by content analysis method in the context of framing perspective. As a result of the analyzes, the most news took place in December, which also coincided with the "closure" period, followed by April and March, which were seen as the "first three months of the pandemic". It was seen that the frames of "informing" and "precaution-protection-warning" were mostly included in the news. In the study, it was determined that there was a statistically significant relationship between the status of the news about the newspapers on the first page, between the newspapers and news frames, and between the frames and the quarterly periods of the pandemic. It has been seen that the related news is mostly found in Hürriyet newspaper.
\end{abstract}

Keywords: Public Relations, Crisis, Covid-19, Framing, Newspapers News 


\section{Giriş}

Covid-19, Dünya Sağlık Örgütü tarafından "pandemi” olarak tanımlanmış küresel ölçekte bir salgın ve sağlık krizidir. Pandemi kavramı ile geniş alana yayılarak çok sayıda insanı etkileyen ve hatta uluslararası sinırları aşan boyutta bir salgın (Porta, 2014, 209) tanımlanırken, genel bir açıklamayla kriz kavramı ile, rutin gidişatı bozan, beklenmeyen bir zamanda ortaya çıkan ve seyri belirsiz bir sürece işaret edilmektedir. Bu doğrultuda Covid-19, bir sağlık krizinden öte, ekonomiden gündelik hayata, eğitimden turizme kadar daha pek çok alanı etkileyen, disiplinler arası bir soruna dönüşmüştür. Salgınla birlikte, kurumların işleyişinden yönetim ve karar alma mekanizmalarına, gündelik hayat pratiklerinden sıradan yaşam alışkanlıklarına kadar pek çok rutin hiç beklenmedik ölçüde değișmiş ve sokağa çıkmak, okula veya alışverişe gitmek, sosyalleşmek gibi "normal" sayılan çok sayıda etkinlik bile sekteye uğramıştır.

Salgının öngörülemez seyri devam ederken, konuyla ilgili çok sayıda akademik çalışma üretilmiş ve hâlihazırda da üretilmektedir. Krizlerin "sürpriz, zaman baskısı ve tehdit" (Pira - Sohodol, 2015, 26) olmak üzere üç temel unsuru üzerinden düşünüldügünnde, süregelen bir kriz üzerine çalışmanın en büyük handikaplarından biri, krizin seyrinin belirsiz doğasına ilişkindir. $\mathrm{Bu}$ doğrultuda pek çok farklı etkisi bulunan salgın çerçevesinde her disiplin, kendi ilgi ve çalışma alanı kapsamında konuyu incelemeye ve analiz etmeye çalışmaktadır. Covid-19 salgını, sağlıktan ekonomiye, sosyolojiden iletişime, risk yönetiminden psikolojiye kadar pek çok farklı alanda incelenmesi gereken bir konu olarak akademik çalıșmaları șekillendirmektedir.

Covid-19 bir sağlık krizi olması bakımından konu, sağlık iletişimi kapsamında da değerlendirilebilir. Çınarlı'nın $(2008,42)$ aktardığı gibi, önde gelen sağlık kuruluşlarından biri olan CDC - Centers for Disease Control and Prevention ${ }^{1}$ tanımına göre sağlık iletişimi, "sağlığı geliştirmek, sağlıkla ilgili kararlar üzerinde etkili olmak ve bilgilendirmek için iletişim stratejilerinin kullanımı"dır. Sağlık iletişimine ilişkin çok sayıda tanımlama olmakla birlikte, sağlık iletişimi araștırmacılarının bir kısmı, kitle iletişim araçlarının sağlıkla ilgili belirli konulardaki anlayışları şekillendirmedeki rolüyle ilgilenmektedir (Wright vd., 2013, 6). Buradan da anlașllacağı gibi bilgilendirme ve bilgi alışverişi süreçleri, sağlık iletişimi açısından önemli ve stratejik bir adımdır. Bilgiye erişimin pek çok farklı yolu olmakla birlikte medya, kamuoyunu bilgilendirme açısından en temel araçlardan biridir. Medya, haberin ve bilginin türlü yollarla aktarımına imkân veren bir yapıya sahiptir. Bunun yanı sıra, mesajların iletiminde temel araçlardan biri de haberlerdir demek mümkündür. Girgin'in $(2000,73)$ açıkladığı gibi; "herhangi bir olayın kitlelere aktarılması" olarak tanımlanabilecek haber, "en etkili medya içeriğidir". Medya ve haberler, bilgi aktarımı ve krizi yönetme açısından da stratejik bir ortaktır. Kriz ve medya arasındaki ilişkiyi ise iki açıdan değerlendirmek mümkündür. Haberlerin aktarılma biçimi, bir yandan endişe ve paniği tetikleyebileceği gibi, bir yandan da bireylerin kriz karşısında ihtiyaç duydukları bilgi açığının giderilmesine katkı sağlayabilmektedir. Ancak bu noktada en önemli husus, bilginin ele alınma, organize edilme ve sunulma biçimidir. Buna göre; doğru, yerinde ve sistematik haber akışları ile yapılan bilgilendirmeler, bireylerin karar alma ve krizleri değerlendirme süreçleri üzerinde olumlu yönde etkiler sağlayabilirken, haberin farklı bağlamlarda sunumu bireyler üzerinde olumsuz etkiler de yaratabilir. $\mathrm{Bu}$ açıdan bakıldığında haberlerin sunumunun ve haberin odak noktasının, kamuoyunun algılama ve anlamlandırma süreci açısından önemli olduğu söylenebilir. 
Covid-19 ise dünyadaki ilk salgın olmasa bile, günümüzde geldiği noktada en ciddi salgınlar listesinde ön sıralarda yerini almıştır ve bir yılı aşkın süredir de devam etmektedir. Buna göre; küresel dünyanın sağlık krizleri ile her geçen gün daha fazla meşgul olduğu (Pan - Meng, 2016) gözlemlenirken, medyanın da domuz gribi, kuş gribi, Ebola, Zika Virüs, SARS, MERS gibi sağlık krizlerinin yanı sıra günümüzde de Covid-19 salgını açısından önemli bir role sahip olduğu (Mutua - Ong'ong'a, 2020, 2) görülmektedir.

Çalışma, medyanın ve özellikle de haberlerin, kriz dönemlerinde önemli bir paydaş olduğu fikrinden hareketle Covid-19 sağlık krizinin/salgınının, ulusal basında ve haberlerde nasıl ele alınarak çerçevelendirildiği ve salgının bir yıllık seyriyle birlikte bu çerçevelerin nasıl değiştiği ya da değişip değişmediği sorusuna odaklanmaktadır. Çerçeve, bir konunun kapsamını ve bağlamını belirleyecek şekilde sunulma sürecidir. Toplumsal gerçekliğin inşasında da aktif rol oynayan haberler ve medya, krize yönelik algıların ya da farklı bir ifadeyle krizin inşasında da etkili bir aktördür.

Çalışma kapsamında, 11 Mart 2020 tarihinde Türkiye'de ilk vakanın görüldüğünün duyurulmasından sonraki bir yıllık sürede, en yüksek tiraja sahip olan üç gazetenin birinci sayfaları incelenecektir. Örneklem seçiminin tiraja dayandırılmasının bir nedeni, geniş kitleleri ilgilendiren bir krizin yine geniş kitleler tarafından tercih edilen gazeteler tarafından nasıl çerçevelendiğinin önemli bir konu olmasıdır. Kamuoyunun krizi algılama ve anlamlandırma biçimleri açısından haberlerin etkili araçlar olabileceği varsayımının yanı sıra gazetelerin ve haberlerin bilgilendirme rolü düşünüldüğünde, küresel bir krize odaklanan bu çalışmada en çok kişiye ulaştığı varsayılan gazetelerin seçilmesi amaçlı bir neden barındırmaktadır. Bu doğrultuda araştırmanın örneklemini 11 Mart 2020 ile Mart 2021 tarihlerinde arasında yayınlanan toplam 1.048 gazete ve 715 haber oluşturmaktadır. Haberler, literatürde yer alan araştırmalardan ve konuyla ilgili daha önce yapılmış benzer çalışmalardan faydalanılarak oluşturulmuş kategoriler ve çerçeveler doğrultusunda analiz edilecektir. Bu çalışma, bir yıllık süreyi kapsaması ve salgının seyriyle bağlantılı olarak haber çerçevelerinde gözlemlenen değișim ve farklılaşmayı ortaya koymayı amaçlaması açısından, literatürdeki diğer çalışmalara ek bir katkı sunmayı amaçlamaktadır. Salgının genel seyri ise, gelecekte konuyla ilgili daha kapsamlı çalışmalara ihtiyaç duyulacağını düşündürmektedir.

\section{Gerçekliğin İnşası Bağlamında Krizin İnşası: Çerçeveleme Üzerine}

Psikolojiden siyaset bilimine, sosyolojiden iletişim çalışmalarına kadar disiplinler arası bir alanda dikkat çeken çerçeveleme çalışmaları, halkla ilişkiler ve iletişim disiplini açısından da önemli bir teorik zemin sunmaktadır. Çerçeveleme analizi, iletişim, sosyoloji ve siyaset bilimi gibi disiplinlerin yanı sıra medya araştırmalarında da giderek daha çok başvurulan popüler bir yöntem haline gelmiştir (Reese, 2001, 7; Wimmer - Dominick, 2014, 162). Teorik bir perspektif olarak çerçeveleme teorisi, bir olay ya da fikrin tüm yönlerini iletmenin mümkün olmadığı anlayışından hareketle "iletişimin seçici doğasından" türemektedir ve bu açıdan bakıldığında her mesaj, doğası gereği bazı unsurların öne çıkmasını sağlarken, bazı unsurları ise geri planda bırakmaktadır (Baden, 2019, 231). İnşacı yaklaşımdan beslenerek sosyal bilimlerde önemli bir zemine oturan çerçeveleme tartışmaları, salgının ve krizin toplumsal alandaki inşasını anlamak açısından yol gösterici olabilmektedir.

İnşacı perspektiften bakıldığında gerçeklik, toplumsal olarak üretilmekte ve yeniden üretilmektedir (Durur, 2011). Bu üretim sürecinde medyanın önemli bir rolü bulunmaktadır. Medyayla bağlantılı olarak haberler de, gerçekliğin şekillenmesi ve toplumsal anlamların oluşumu açısından işlevseldir. Riegert ve Olsson'un $(2007,143)$ 
ifade ettikleri gibi, "gazetecilik, bilgi sağlamak kadar anlam oluşturmakla da ilgilidir". Haber ve gerçeklik arasındaki ilişki yeni bir tartışma olmamakla birlikte Dursun'un açıklamasıyla $(2004,37)$ haber üretiminin özünün, seçme ve seçilmişleri bir araya getirme işlemi olması nedeniyle haberin "toplumsal gerçekliği inşa ettiği-kurduğu" söylemi, haberde tarafsızlığın mümkün olmadığına işaret eden pek çok çalışmada vurgulanmaktadır.

$\mathrm{Bu}$ doğrultuda haber ve gerçeklik arasında "sorunlu bir bağlantı" (Dursun, 2004, 40) olduğu varsayılmaktadır. Öte yandan haberin, günlük hayatımızdaki önceliklerimize ve algılarımıza ilişkin bakış açılarımız üzerinde de belirleyici olduğu yaygın bir söylemdir. Berger ve Luckmann'ın $(2008,35,37)$ "önceden düzenlenmiş gerçeklikler" olarak tanımladıkları gündelik hayatın gerçeklikleri ise, onlara dair kavrayışlarımızdan bağımsız gibi görünen, ancak kendilerini kavrayıșlarımıza dayatan örüntüler tarafından düzenlenmişlerdir. Yazarlara göre bu gerçeklikler olduğu gibi kabul edilirken herhangi bir doğrulama gerektirmemektedirler.

Sosyolojik bir perspektiften ise, ilk kez Erving Goffman'ın çerçeveleme araştırmaları üzerinde durduğu söylenmektedir (Durur, 2011; Seyidov, 2014; Özarslan - Güran, 2015; Baden, 2019; Kılıç, 2021). Goffman'ın (1986, 21, 24) ifadeleriyle çerçeveler, bireylerin olayları ve yaşam deneyimlerini "konumlandırmasını, algılamasını ve tanımlamasını" sağlayan yorumlama şemalarıdır ve "kullanılan çerçeve türü, uygulandığı olayı tanımlamanın bir yolunu sağlamaktadır".

Goffman'ın yanı sıra çerçeveleme üzerine literatür incelendiğinde, iletişim ve medya çalışmaları kapsamında Robert M. Entman'a yapılan göndermeler dikkat çekicidir. "Seçim" ve “belirginlik" kavramlarına odaklanan Entman'a $(1993,52)$ göre; çerçeveleme kısaca, "algılanan bir gerçekliğin bazı yönlerini seçmek ve bunları bir iletişim metninde daha belirgin hale getirmektir". Bir başka çalışmada çerçeveleme, "hem bireysel psikolojik bir süreç, hem örgütsel bir süreç ve ürün, hem de politik stratejik bir araç" olarak tanımlanmıştır (Entman vd., 2009, 175).

Medya bir yandan toplumsal gerçekliğin inşası sürecinde rol oynarken, bir yandan da kamuoyuna çeşitli hikâyeler anlatmaktadır. Poirier ve diğerlerinin ifadesiyle "bu hikâye anlatma sürecine çerçeveleme" $(2020,365)$ denilmektedir. Çerçeveleme, "olayları ve dünyayı anlamlandırma" (Narin, 2008, 55) biçimimiz üzerinde de etkilidir ve çerçeveler, kamuoyunu şekillendiren güçlü mekanizmalardır (Knight, 1999, 381). Bir başka açlklamaya göre ise "çerçeveler, izleyicilerin sosyal dünyalarındaki olaylara ilişkin algılarını değiştiren bilişsel filtreler görevi görmektedir" (Mason, 2014, 81).

Bunların yanı sıra medya metinleri, toplumsal ve kültürel yapı kapsamında üretilmektedir (Durur, 2011, 29). Bu bağlamda kültür, "bir toplumdaki bireylerin zihninde yaygin olarak bulunan şema stoku" (Entman, 1993, 53; Entman, vd., 2009, 176) olarak tanımlanmıştır. Anlamlandırma pratiği olarak da açıklanan çerçeveleme kapsamında ise, "anlam, inşa edilen bir şey olarak ele alındığında, aynı olay ya da olgulara farklı anlamlar yüklenebileceği sonucu ortaya çıkmaktadır” (Durur, 2011, 22-23).

Krizler açısından çerçeveleme tartışmaları incelendiğinde, Michiel S. de Vries'in (2004) çalışması dikkat çekmektedir. Yazar çalışmasında, çerçeveleme teorisinin krizlere nasıl uygulanabileceği ve krizlere verilen tepkileri anlamamıza nasıl yardımcı olabileceği sorusuna odaklanmış ve havai fişek fabrikalarında meydan gelen krizleri bu çerçevede incelemiştir (de Vries, 2004, 599). Bu açıdan bakıldığında, literatürde sağlık krizleri de dâhil olmak üzere farklı türden krizlerin medyada nasıl çerçevelendiğine odaklanan çok sayıda araştırmaya (Liu - Kim, 2011; Pan - Meng, 2016; Damstra - Vliegenthart, 2018; 
Saraç, 2018; Choi - McKeever, 2019; Pieri, 2019) rastlamak mümkündür. Bu durum, krizin medyada ele alınma biçimi doğrultusunda çerçeveleme perspektifinin önemli bir bakış açısı sunduğunun da göstergesi niteliğindedir. İfade edildiği gibi "izleyicilerin kriz algısının genellikle, gazeteciler tarafından şekillendirildiği ya da değiştirildiği söylenmektedir" (Poirier vd., 2020, 365).

Haber çerçeveleri, sadece salgınla ilgili "kamu söylemini şekillendirmede değil, aynı zamanda salgın yönetimi müdahalelerinin iletişiminde de önemli bir unsur haline gelmiştir" (Mutua - Ong'ong'a, 2020, 1). Bu noktada halkla ilişkilerin de bir parçası olan kriz veya salgın/pandemi yönetimi süreci kapsamında bakıldığında çerçevelemenin "halkla ilişkiler mesajlarının ve izleyici tepkilerinin stratejik yaratılmasını incelemek için potansiyel olarak faydalı bir paradigma" (Hallahan, 1999, 205) olduğu söylenmektedir.

\section{Salgın ve Kriz Döneminde Habercilik ve Medya}

Kriz dönemleri, iletişimin ve haber ile bilgi akışının hayati olduğu zaman dilimleridir. Krizden doğrudan ya da dolaylı olarak etkilenen pek çok insan için medyada yer alan haberler, yegâne bilgi kaynağı haline gelebilmektedir. Larsson'un $(2010,716)$ ifadesiyle medya, "vatandaşlara ulaşan en önemli bilgi yolunu oluşturmaktadır". Kriz esnasında medyadan aktarılan bilgiler kamusal algı üzerinde önemli bir etki yaratırken (Pira Sohodol, 2015, 220) aynı zamanda medyanın doğru bilgi sağlamada etkin bir rol oynaması da beklenmektedir (Riegert - Olsson, 2007). Bu doğrultuda bilgi arayışının yoğun olduğu kriz dönemlerinde, bir yandan bilgi toplama, bir yandan da bilgi yayma çabaları (Pira Sohodol, 2015, 230) medyayı ve bununla bağlantılı olarak haberleri, kriz yönetim sürecinde stratejik bir ortak haline getirmektedir. Her geçen gün daha fazla sayıda küresel ölçekte kriz ile karşı karşıya kalındığı günümüzde, ana akım haber medyasının küresel krizlerin görselleştirildiği, dramatize edildiği, anlatıldığı ve kamuoyuna açıklandığı yer olduğu belirtilmektedir (Cottle, 2009). Heath'in (2010, 1) de açıkladığı gibi; "medya haberciliği, kriz koşullarını yalnızca tanımlamakla kalmamakta, aynı zamanda da dikkat çekici hale getirmektedir."

Pek çok insan doğrudan ya da dolaylı olarak krizi deneyimlemese bile, medya aracılığıyla krizden haberdar olmaktadır (Holladay, 2010, 161). Krize yönelik algının, krizin haberlerde nasıl aktarıldığı ve nasıl ele alındığıyla ilgili olduğunu söylemek mümkündür. Kimi çalışmalar krizin medyada yer alış biçimiyle krizin seyri, krize yönelik algı ve krize karşı verilen tepkiler arasındaki ilişkiye dikkat çekmişlerdir (Ma, 2005; Schultz vd., 2011; Iannarino vd., 2015; Kim, 2016). Bununla bağlantılı olarak kriz iletişimi uzmanlarının çerçeveleme teorisini, medyanın krizi karakterize ediş biçiminin halkın olayı algılayıșını etkileyebileceğini açıklamak için kullandıkları söylenmektedir (Iannarino vd., 2015, 169).

Covid-19 salgını gibi kriz dönemlerinde medya, insanların bilgi edinmesi süreci açısından muazzam bir bilgi yükü sunmaktadır (Ogbodo vd., 2020, 257). Salgınla birlikte infodemi kavramı ekseninde gündeme gelen tartışmalar, ortaya çıkan haber, bilgi ve enformasyon fazlalığına işaret ederken medya, bu durumu destekleyici bir role sahiptir. Doğru olan ya da olmayan bilgilerin bolluğuna (PAHO, 2020) işaret eden infodemi kavramı, aynı zamanda "bilgi kirliliği” olarak da değerlendirilmektedir. Sarığlu ve Turan'ın $(2020,821)$ ifade ettikleri gibi kavram, "sanal ortamda hızla yayılan dezenformasyonu" açıklamak için de kullanılırken, bu kirliliğin bir nedeni de "medyada daha önce görülmemiş oranda artan bilgi paylaşımlarıdır". Dezenformasyon ise bir anlamda, eksik, hatalı, yanlış ya da yanıltıcı bilginin yayılımıyla ilgili bir kavram olup (Fetzer, 2004) salgının ilk anından itibaren özellikle dijital medyanın, yanlış bilginin ve dezenformasyonun yayılması açısından önemli bir etkiye sahip olduğu dikkat çekmiștir (Nguyen - Catalan, 2020). Pereira ve 
diğerlerinin $(2020,1)$ vurguladıkları gibi, "internet tarafından desteklenen modern bilgi ağlarının yardımıyla, komplo teorilerini, yanlış haberleri ve sağlıkla ilgili aldatmacaları yayan koordineli dezenformasyon kampanyaları, her zamankinden daha yaygındır".

Bunların yanı sıra salgın süreci, kriz haberciliği olarak da adlandırılabilecek habercilik türü açısından da önemli bir dönemdir. Bu doğrultuda salgınların ya da krizlerin, "seyirlik bir öykü" gibi algılanarak sansasyonel bir biçimde sunumunun, endişe, panik ve korku duygularını pekiștireceği ifade edilirken haberlerin, krizi yeniden üretebilme potansiyeli olduğu da vurgulanmaktadır (Çaplı - Taş, 2010). Bahsedilen bu endişe durumu ise aynı zamanda medyada yer alan haberlerle de bağlantılı olabileceği gibi literatürdeki kimi çalışmalar, salgın sırasında yayılan haberlerin ve sosyal medya kullanımlarının neden olduğu korku, kafa karışıklığı ile güvensizlik duygusuna odaklanmışlardır (Tagliabue vd., 2020; Gülnar - Acar, 2021).

Öte yandan, Covid-19 salgını aynı zamanda bir sağlık krizi olması bakımından konu, sağlık haberciliği açısında da ele alınabilmektedir. Buna göre; salgın sürecinde, kamuoyuna doğru sağlık bilgileri aktarıldığında bireylerin tehdit ve risklere yönelik algıları iyileşmekte, ancak medyanın bu yönde bilgi yayamadığı durumlarda ise aksine, belirsizlik ve panik beslenmektedir (Mutua - Ong'ong'a, 2020, s. 2). Bu nedenle haber medyasının, özellikle bulaşıcı hastalıklarla ilgili sağlık ve risk bilgileri üzerindeki rolünü (Pan - Meng, 2016) ve kamuoyu algısı ile karar verme üzerinde etkisini (Fearn-Banks, 2017, 23; Ogbodo vd., 2020, 257) anlamak gerekmektedir.

\section{Amaç ve Yöntem}

Covid-19 sağlı krizine ilişkin haberlerin çerçeveleme bakış açısı bağlamında incelenmesine ve analizine dayanan bu çalışma, küresel sağlık krizinin haberlerde nasıl ele alındığını, hangi unsurlara odaklanıldığını ve salgının seyriyle birlikte haberlerin içeriklerinin ve çerçevelerin nasıl değiştiğini görmek açısından önemlidir. Öte yandan her çalışma, doğası gereği belirli sınırlılıklar içermektedir. Bu çalışma ise yazılı basında en yüksek tiraja sahip ilk üç gazete ile sınırlandırılmakla birlikte, ele alınan haberlerin 12 ay gibi geniş bir zaman dilimini kapsadığını söylemek mümkündür. Buna göre çalışmanın örneklemini, Türkiye'de resmi olarak ilk vakanın görüldüğünün açıklanmasından itibaren geçen bir yıllık zaman diliminde en yüksek tiraja sahip üç gazetenin haberleri oluşturmaktadır. Çalıșmada, 11 Mart 2020 tarihinden başlayarak Mart 2021 tarihine kadar Hürriyet, Sabah ve Sözcü gazetelerinin birinci sayfaları inceleme kapsamında alınmıştır.

Birinci sayfalar incelenirken, sayfada genellikle birden fazla haber olduğu görülmüş ve haber seçimlerinde de bir sınırlandırmaya gidilmiştir. Bu açıdan bakıldığında amaçlı örneklem yöntemiyle birinci sayfalarda yer alan bazı haberler seçilerek analiz kapsamına alınmıştır. Bu doğrultuda çalışma, gazetelerde yer alan tüm Covid-19 haberlerini analiz ettiği iddiası taşımamaktadır ve bu durum, araștırmanın temel bir sinırlılığı olarak düşünülebilir. Öte yandan böyle bir sınırlandırmaya gidilmesinin çeşitli nedenleri bulunmaktadır. Yapılan ön analizler sırasında gazetelerin birinci sayfalarında manșet, sürmanşet, haber kısaları, anonslar, haber başlıkları gibi çok sayıda habere yer verildiği gözlemlenmiştir. Konuyla ilgili yürütülen bir başka çerçeveleme çalışmasında da belirtildiği gibi, gazetelerde sunulan haberlerin sayfadaki konumları incelendiğinde haberlerin "sayfa eteği, manşet altı, duyuru biçiminde ve manşet ile sürmanşet" olarak (Kılıç, 2021, 326) verildiği görülmektedir. Bu haberlerin bir kısmında, haberin içeriğine dair kısmi ve sınırlı bilgiler yer almakla birlikte çok sayıda haberin yalnızca başlık olarak verildiği görülmüștür. Örneğin; anons, haber kısası, duyuru ya da haber başlıkları gibi 
içerikler, genellikle haberi kısmi olarak sunan biçimler olduğundan dolayı, kimi durumlarda bu haberler üzerinden haberin net olarak çerçevesinin belirlenmesi zorlaşmaktadır. Bu noktada daha objektif bir analiz yürütebilmek için, özellikle haberin detaylarının daha açlk olduğu manșetler ve sürmanşetler öncelikli olarak seçilmiş, ancak birinci sayfada öne çıkan ve habere ilişkin detaylı bilgilerin aktarıldığı diğer haber kısaları da araştırmacılar tarafından ortak olarak kararlaștırılarak analiz kapsamına alınmıştır. Konuyla ilgili önemli haberlerin analiz dışında kalmaması amacıyla, araștırmacılar tarafından amaçlı bir örneklem seçimine gidilmiştir. Bu seçimler sonucunda 12 ayda üç gazeteden elde edilen toplam 715 haber analiz kapsamına alınmıştır. Öte yandan 12 ayda analiz edilen gazetelerden, 489 gazetenin birinci sayfasında ise Covid-19 ile ilgili habere rastlanmamıştır. Buna göre incelenen 12 ayda üç gazetenin toplamda 1.0482'inin birinci sayfası incelenmiş bunların 489'unda kodlamaya dâhil edilen herhangi bir haber olmamış, kalan 559 gazetenin birinci sayfasından ise toplamda 715 haber analiz için derlenmiştir.

Haberlerin kodlama işlemleri sırasında ise şu unsurlara dikkat edilmiştir. Birinci sayfada konuyla ilgili birden fazla haberin olması durumunda haberlerin her biri, ayrı ayrı kodlanmıştır. Kodlama sırasında haberin çerçevesinin belirlenmesinde hem başlık, hem de haber metninde yer alan bilgiler dikkate alınarak haber, tek çerçeve kategorisine kodlanmıştır. Haberde birden fazla çerçeveyi temsil eden bilgilerin olması durumunda ise, özellikle başlıkta yer alan vurgular yönlendirici kabul edilerek buna göre kodlama yapılmıştır. Başlık, ilk dikkat çeken ve haberin vermek istediği mesajdaki öncelikli anlamı aktaran unsurlar olduğundan dolayı, başlıkta yer alan vurgulara ayrıca dikkat edilmiştir.

Çalışmada şu sorulara yanıt aranmıştır: "Covid-19 ile ilgili haberler, üç gazetede nasıl çerçevelendirilmektedir ve bu çerçevelerin dağılımları nasıldır?”, "Gazetelere göre en çok kullanılan çerçeveler arasında anlamlı farklılıklar var mıdır?”, "Salgının seyriylebağlantılı olarak kullanılan çerçevelerde bir farklılaşma veya değişim var mıdır?", "Salgının seyrine ve kapanma ile normalleşme süreçlerine bağlı olarak haber çerçevelerinin değişimi ile aylar arasında anlamlı farklılaşmalar var mıdır?"

İnşacı yaklaşım ve çerçeveleme kuramı ekseninde betimleyici bir analiz gerçekleştirmek amacıyla haberler içerik analizi yöntemiyle incelenirken, araştırmanın analiz kategorileri ise literatürdeki çok sayıda araştırma doğrultusunda oluşturulmuştur. İçerik analizi, "sistematik ve nesnel olarak iletişimin görünen içeriğini tanımlamak ve duruma göre çıkarımlar yapmak için kullanılan bir teknik" (Ogbodo vd., 2020, 259) olarak tanımlanmaktadır ve Neuman'ın $(2014,49)$ belirttiği gibi daha çok betimleyici amaçlar için kullanılmaktadır. Wimmer ve Dominick $(2014,162)$ ise, haber medyasının konuları nasıl çerçevelediğini belirlemek ve açıklamak için araştırmacıların içerik analizini kullandığını belirtmişlerdir.

Literatür taraması ve örneklemin yüzde 10'u üzerine gerçekleştirilen ön analiz sonucunda kodlama için sekiz çerçeve belirlenmiş ve bunlar iki farklı kodlayıcı tarafından kodlanmıştır. Verilerin analizi SPSS 26.0 programı ile yapılmış ve \%95 güven düzeyi ile çalışılmıştır. Kategorik (nitel) değişkenler için frekans (n), yüzde (\%) istatistikleri verilmiştir ve çapraz tablolardan faydalanılmıştır. Çalışmada değişkenler arasındaki ilişkilerin belirlenmesi amacıyla ki-kare $\left(\chi^{2}\right)$ testi kullanılmıştır. Ki-kare $\left(\chi^{2}\right)$ testi, iki kategorik değişken arasındaki iliş̧iyi incelemek ve ilişkiyi belirlenmekte kullanılan test tekniğidir (Tabachnick - Fidell, 2015). Çalışmada ayrıca Phi ilişki katsayısı da verilmiştir. Phi ilişki katsayısı ikili değişkenler için ilişkinin ölçüsü olup değişkenlerin her ikisi de ikili ise, bu iki kategorili süreksiz iki değişken arasındaki ilișki "Phi" adı verilen bir ilişkisel teknik aracılığıyla değerlendirilir (Ekström, 2011; Huck, 2012). 
Çerçevelere ilişkin fikir ayrılığı ve revizyon ihtiyacı olan durumlarda kodlama kılavuzu gözden geçirilerek son haline erişilmiştir. Örneklemin tamamı iki araştırmacı tarafından kodlanmış, kararsızlık yaşanan durumlarda üçüncü bir araştırmacının desteğine başvurulmuş ve çalışma için kodlayıcılar arası uyumu gösteren alfa $(\alpha)$ değeri hesaplanmıştır. Krippendorff alfa $(\alpha)$ değerinin çalışmanın güvenirliği arttırmak için hesaplanması sırasında Hayes ve Krippendorff'un (2007) açıkladıkları yönteme başvurulmuştur. Kodlayıcılar arası uyumun " $\alpha=1$ " olması mükemmel güvenilirliği gösterirken aynı zamanda alfa değerinin 1 olması kodlayıcıların tam olarak hemfikir olduklarının da işaretidir. Çalışmanın güvenilirlik değeri $\alpha=0.8907$ olarak hesaplanmıştır. Krippendorff $(2004,241)$ çalışmasında, $\alpha=0.800$ üzeri değerlerin güvenilir olduğunu belirtmektedir. Buna göre mevcut çalışmanın kodlayıcılar arası uyumunun yüksek olduğu söylenebilir.

Literatürde COVID-19 salgını ve çerçeveleme üzerine yapılan çalışmalara rastlamak mümkündür (Ogbodo vd., 2020; Poirier vd., 2020; Nwakpu vd., 2020; Mutua - Ong'ong'a, 2020; Kutlu, 2020; Wibhisono, 2020; Madsar, 2020; Yılmaz Altuntaş, 2021; Cılızoğlu vd., 2021; Kılıç, 2021). Türkiye'de bu kapsamda tespit edilebilen ilk çalışma Kutlu (2020) tarafından yapılmış olup çalışmada, Türkiye'deki çevrimiçi medyada Covid-19 haberlerinin nasıl çerçevelendiğini anlamak amacıyla "ensonhaber.com" sitesinde 26 Şubat-10 Mart ve 11-26 Mart 2020 tarihleri arasında yayınlanan haberler incelenmiş ve karşılaştırılmıştır. Madsar (2020) çalışmasında 11 Mart-10 Nisan 2020 tarihleri arasında Cumhuriyet, Sözcü, Yeni Akit ve Yeni Şafak gazetelerinin ilk sayfalarında yer alan Covid19 haberlerini çerçeveleme perspektifinden ele almıştır.

Konuyla ilgili dikkat çeken bir diğer çalışma ise, Yılmaz Altuntaş (2021) tarafından yapılmıştır. Yılmaz Altuntaş'ın çalışmasında, 1 Aralık 2019 ile 12 Temmuz 2020 tarihleri arasında Alexa.com sitesine göre en çok etkileşim alan Covid-19 ile ilgili haberlerin konu türleriyle etkileşim oranları bağlamında nasıl çerçevelendiği, içerik analizi yöntemiyle incelenmiştir. Cılızoğlu, Dondurucu ve Çetinkaya (2021) tarafından yürütülen bir diğer çalışmada ise İngiltere'den The Sun, Türkiye'den Hürriyet gazeteleri örneklem olarak alınmış ve 1-31 Ekim 2020 tarihleri arasındaki salgın konulu haberlerinin çerçeveleme biçimleri analiz edilmiştir. Son olarak Kılıç (2021) çalışmasında, yazılı basında Covid-19 ile ilgili haberlerin nasıl çerçevelendiğini incelemeyi amaçlamış ve bu amaçla, farklı ideolojik duruşları temsilen Sözcü, Sabah, Hürriyet, Türkiye ve Cumhuriyet gazetelerinin birinci sayfalarında 9 Mart 2020 - 5 Nisan 2020 tarihleri arasında yer alan haberleri incelenmiştir.

Öte yandan literatür taraması sırasında, Covid-19 aşı haberlerinin çerçevelenmesine ilişkin Kazaz, Pala ve Kazaz (2021) tarafından yürütülen bir araştırma olduğu da görülmüştür. İçerik analizinin uygulandığı bu çalışmada yazarlar, ulusal ve uluslararası medyada aşı haberlerinin nasıl sunulduğunu ortaya koymak amacıyla Türkiye'de Faz 3 çalışmalarının başladığı 16 Eylül 2020 tarihinden 16 Ekim 2020 tarihine kadar Sputnik, Independent, DW, BBC, Hürriyet, Sabah, Haber Türk, Sözcü, T24 ve Dokuz8 Haber'in internet sitelerinde yer alan aşı haberlerini incelenmişlerdir.

Çerçeveleme araştırmalarına ilişkin literatür incelendiğinde ise, araştırma kapsamında kullanılması muhtemel çerçevelerin tanımlandığı çok sayıda çalışma olduğu görülmüştür. Örneğin incelenen çok sayıda çalışmanın referans verdiği Semetko ve Valkenburg (2000) çalışmalarında, "sorumluluk yükleme, çatışma, insan ilgisi, ekonomik sonuçlar ve ahlak" olmak üzere beş çerçeveye işaret etmişlerdir. Bu çerçevelerden "insan ilgisi, ekonomik sonuçlar ile ahlak" çerçeveleri mevcut araştırmanın kodlama cetveline dâhil edilmiştir. 
Aynı zamanda bu çerçevelere, Ogbodo ve diğerleri (2020) tarafından Covid-19 haberlerinin küresel medya çerçevelerini inceledikleri çalışmada da rastlanmıștır. Bu kategorilere ek olarak, Ogbodo ve diğerlerinin $(2020,259)$ kendi araştırmalarında kullandıkları üç çerçeve daha analiz kapsamına alınmıştır. Bunlar, "siyasileştirme, korku ve umut" çerçevesi olarak kavramsallaştırılmıștır.

Son olarak, Kutlu'nun (2020) çalışmasında kullandığı "eylem" ve "güvence" çerçevesi ile Saraç'ın (2018) domuz gribi haberlerinin çerçevelemesini incelediği çalışmasında kullandığı "tedbir ve kontrol", "riskli gruplar ve bilgi verme" ve "alarm/uyarı" çerçeveleri mevcut araştırmaya uygun hale getirilerek yeni çerçeveler belirlenmiştir. Bu doğrultuda mevcut araştırmaya "tedbir-önlem-uyarı" ile "bilgi verme" kategorileri eklenmiştir. Araştırmanın analiz çerçeveleri ve bu çerçevelere ilişkin tanımlar Tablo 1'de sunulmaktadır.

Tablo 1: Çalışmada Kullanılan Çerçeveleme Kategorileri ve Açıllamaları

\begin{tabular}{|c|c|}
\hline Çerçeve Kategorileri & Açıklama - Tanım \\
\hline İnsan ilgisi & $\begin{array}{l}\text { Salgın ile bağlantılı hastalık veya kayıp gibi sıradan insan hikâyelerine, } \\
\text { olayın duygusal etkilerine, insani durumlara odaklanan haberler ve } \\
\text { özellikle sağlık çalışanları hikâyeleri }\end{array}$ \\
\hline Ekonomik sonuçlar-destek-dayanışma & $\begin{array}{l}\text { Salgının ekonomik etkilerine ve sonuçlarına odaklanılan, ekonomik } \\
\text { olarak zarara uğrayanlara yapılan yardımları, teşvikleri, destek } \\
\text { çalışmalarını içeren haberler }\end{array}$ \\
\hline Siyasileştirme-eleştiri & $\begin{array}{l}\text { Salgının siyasi perspektiften ve siyasi aktörler çerçevesinde } \\
\text { değerlendirilmesini içeren veya salgın yönetim süreçlerini eleștiren } \\
\text { haberler }\end{array}$ \\
\hline Tedbir-önlem-uyarı & $\begin{array}{l}\text { Salgına yönelik bireysel ya da yönetsel olarak uygulanan, tedbir ve } \\
\text { önlemler ile korunma yollarını anlatan, sokağa çıkma yasağı gibi } \\
\text { önlemleri içeren ve bireyleri tedbir almaları ve bu tedbirleri nasıl } \\
\text { almaları gerektiği konusunda uyaran haberler }\end{array}$ \\
\hline Korku & $\begin{array}{l}\text { Kamuoyunda korku veya panik yaratabilecek haberler, örneğin hasta } \\
\text { sayılarındaki artıș, yan etkiler ve salgının seyriyle ilgili endișe verici } \\
\text { bilgiler }\end{array}$ \\
\hline Umut & $\begin{array}{l}\text { Kamuoyuna umut ve güven veren hikâyeler ve mesajlar, örneğin aşı ya } \\
\text { da tedavi yöntemlerinde gelişmeler, salgının seyrinin kontrol altında } \\
\text { olduğunu ve normalleşme süreçlerini vurgulayan, sayıların azaldığını } \\
\text { belirten haberler }\end{array}$ \\
\hline Bilgi verme & $\begin{array}{l}\text { Salgın ile ilgili genel bilgiler, örneğin online eğitimin nasıl } \\
\text { gerçekleşeceği, günde kaç test yapıldığı, gündelik sunulan veriler gibi } \\
\text { genel bilgileri içeren nötr haberler }\end{array}$ \\
\hline Ahlak/etik & $\begin{array}{l}\text { Salgının ahlaki ve etik sorumluluk boyutları, örneğin tedbir, önlem ve } \\
\text { kurallara uymayanlara, kendini ve başkalarını tehlikeye atanlara, krizi } \\
\text { fırsata çevirmeye çalışanlara ișaret eden haberler }\end{array}$ \\
\hline
\end{tabular}

Son olarak, araştırmanın kodlama cetvelini Tablo 2'de görmek mümkündür. 
Tablo 2: Kodlama Cetveli

\begin{tabular}{|c|c|}
\hline Gazete adı & $\begin{array}{l}\text { Hürriyet } \\
\text { Sabah } \\
\text { Sözcü }\end{array}$ \\
\hline Aylar & $\begin{array}{l}\text { Mart } 2020 \text { / Nisan } 2020 \text { / Mayıs } 2020 \text { / Haziran } 2020 \text { / Temmuz } 2020 \text { / Ağustos } 2020 \\
\text { / Eylül } 2020 \text { / Ekim } 2020 \text { / Kasım } 2020 \text { / Aralık } 2020 \text { / Ocak } 2021 \text { / Şubat } 2021\end{array}$ \\
\hline Aylık periyotlar & $\begin{array}{l}\text { Salgında ilk üç ay : Mart } 2020 \text { / Nisan } 2020 \text { / Mayıs } 2020 \\
\text { Normalleşme - tatil süreci : Haziran } 2020 \text { / Temmuz } 2020 \text { / Ağustos } 2020 \\
\text { Sonbahar önlemleri : Eylül } 2020 \text { / Ekim } 2020 \text { / Kasım } 2020 \\
\text { Kapanma ve aşılama-aşı çalışmaları : Aralık } 2020 \text { / Ocak } 2021 \text { / Şubat } 2021\end{array}$ \\
\hline Salgın ile ilgili haber & $\begin{array}{l}\text { Var' }^{3} \\
\text { Yok }\end{array}$ \\
\hline Çerçeve & $\begin{array}{l}\text { İnsan ilgisi } \\
\text { Ekonomik sonuçlar-destek-dayanışma } \\
\text { Siyasileştirme-eleştiri } \\
\text { Tedbir-önlem-uyarı } \\
\text { Korku } \\
\text { Umut } \\
\text { Bilgi verme } \\
\text { Ahlak/etik }\end{array}$ \\
\hline
\end{tabular}

\section{Araştırma Bulguları}

11 Mart 2020 tarihinden Mart 2021 tarihine kadar olan 12 ay boyunca, incelenen üç gazetede toplamda 1.048 birinci sayfa incelenmiş, ancak bunların 489'unda araștırma kapsamına alınacak herhangi bir habere rastlanmamıştır. Geri kalan 559 gazetenin birinci sayfalarından Covid-19 ile ilgili toplam 715 haber araştırma kapsamına alınmıştır. Daha önce de belirtildiği gibi bazı günlerde birden fazla haber kodlamaya dâhil edilmiștir. 715 haberin aylara göre dağılımını Tablo 3'te görmek mümkündür.

Tablo 3: Haberlerin Aylara Göre Dă̆llımı

\begin{tabular}{l|c|c}
\hline & n & \% \\
\hline Mart & 93 & 13,0 \\
Nisan & 94 & 13,2 \\
Mayıs & 45 & 6,3 \\
Haziran & 49 & 6,9 \\
Temmuz & 13 & 1,8 \\
Ăgustos & 33 & 4,6 \\
Eylül & 42 & 5,9 \\
Ekim & 39 & 5,5 \\
Kasım & 68 & 9,5 \\
Aralık & 117 & 16,4 \\
Ocak 2021 & 71 & 9,9 \\
Şubat 2021 & 51 & 7,0 \\
\hline
\end{tabular}

Aylara göre dağılıma bakıldığında en çok haberin sırasıyla Aralık $(\% 16,4)$, Nisan $(\% 13,2)$ ve Mart $(\% 13,0)$ aylarında olduğu görülmüștür. Aylara göre en az haber ise, 13 haber ile $(\% 1,8)$ Temmuz ayındadır.

Analizler yürütülürken, çalışma kapsamında incelenen tarihler salgının seyrine göre üçer aylık periyotlara ayrılmıştır. Bu ayrım gözetilirken salgın sürecinde yaşanan değişimler, salgının gelişim ve dönüşüm süreci ve salgında dikkat çeken tarihler gözetilmiştir. Buna göre 12 aylık dönem üçer aydan dört periyota ayrılmıştır. Bu periyotlar; "Mart, Nisan, Mayıs" olmak üzere "salgında ilk üç ay", "Haziran, Temmuz, "Ağustos olmak üzere "normalleşme-tatil süreci”, "Eylül, Ekim, Kasım” olmak üzere "sonbahar önlemleri” ve "Aralık, Ocak 2021, Şubat 2021" olmak üzere "kapanma ve aşılama-aşı çalışmaları" olarak ayrılmıştır. Bu ayrım gözetilirken gazetelerde yer alan haberler ve haberlere ilişkin çeşitli bulgular belirleyici olmuştur. 
Örneğin, araştırma sırasında dikkat çeken önemli bulgulardan biri Mart ve Nisan aylarında konuyla ilgili manşetlere yansıyan daha çok haberin oluşudur. Daha önce de belirtildiği gibi salgınla ilgili haberlere, manşet, sürmanșet, haber kısası, anons, haber başlığl, sayfa altında yer alan haberler gibi çeşitli șekillerde rastlamak mümkündür. Manșet, en çok dikkat çeken haberin vurgulandığı alan olup bir haberin manşette yer alışı konunun, gündemdeki önemine de işaret etmektedir. Bu doğrultuda salgının ilk üç ayı kamuoyu açısından henüz yeni olan bir krizi tanıma, anlama ve anlamlandırma süreci olarak da görülebilir.

Periyotların belirlenmesinde dikkat çeken bir diğer önemli bulgu, 29 Mayıs 2020 tarihinde yayınlanan Hürriyet gazetesinin "1 Haziran Milat Oldu" manşetidir. Bu habere göre ülke genelinde uygulanan kısıtlamaların büyük bir bölümünün 1 Haziran itibariyle kaldırılması gündemdedir. Aynı tarihte Sabah gazetesinin manşeti ise "1 Haziran'da Normal Hayat" olmuştur. Bu haberde de kısıtlamaların kaldırılacağına ilişkin haber detayları yer almaktadır. Bu nedenle Haziran ayı "normalleşme" ayı olarak belirlenirken Temmuz ve Ağustos aylarında da salgınla ilgili az sayıda haber oluşu, haberlerin daha genel bir şekilde seyretmesi, normalleşme ve tatil süreçlerine yapılan vurgular gibi nedenler, bahsedilen üç ayın "normalleşme ve tatil süreci" olarak sınıflandırılmasında etkili olmuştur. Öte yandan, 1 Eylül 2020 tarihli Hürriyet gazetesinde "Şehir Şehir Anlattı" manşetinin altında "Koronada Sonbahar Önlemleri" alt başlıklı bir haber bulunmakta ve bu haberin detayında "Sağlık Bakanlığı, sonbaharda olası vaka artışına karşı yeni önlemler planlıyor" bilgisi yer almaktadır. İncelenen her üç gazetede de Eylül ayı itibariyle haberlerin genel olarak tatil ve normalleşme sürecinden sonra salgının seyrine, vakalardaki artışa ilişkin endișeleri barındırdığı ve alınması muhtemel yeni önlemleri işaret ettiği gözlemlenmiştir.

Aralık ayı itibariyle ise salgının seyrinin yeniden endișe verici noktaya geldiği haber başlıklarında da görülmektedir. 1 Aralık 2020 Hürriyet gazetesi manșeti “21:00'den Sonra Sokak Yok", Sabah gazetesi manșeti "Hafta Sonları Tam Kapanma", Sözcü gazetesi haberi ise "Yoğun Bakımlar Yüzde 100 Doldu" șeklindedir. Bu nedenle Aralık ayı "kapanma" olarak kodlanmışken, Ocak 2021 ve Şubat 2021 tarihlerinde ise kapanma haberlerinin yanı sıra yoğun bir biçimde aşı ve tedavi haberlerinin artışa geçtiği görülmüştür. Bu nedenle Aralık, Ocak 2021 ve Şubat 2021 aylarını kapsayan üç aylık dönem "kapanma ve aşılama-aşı çalışmaları" periyotu olarak adlandırılmıştır. Haberlerin periyodik olarak dağılımlarına bakıldığında en çok haberin "kapanma ve aşılama-aşı çalışmaları" (n= 239, $\% 33,42$ ) döneminde olduğu görülmüștür. Ancak genel haber akışlarına bakıldığında, "salgında ilk üç ay" ( $\mathrm{n}=232, \% 32,44$ ) olarak adlandırılan ilk dönemden sonra haberlerde bir düşüş yaşandığı, en düşük haber akışının "normalleşme-tatil süreci" döneminde (n= 95, \%13,28) olduğu, "sonbahar önlemleri" (n= 149, \%20,83) olarak kavramsallaştırılan üçüncü dönemde haberlerin artışa geçtiği ve başta da belirtildiği gibi kapanma dönemi itibariyle en yüksek seviyelere ulaştığı bulgulanmıştır.

Haberlerde kullanılan çerçevelere ilişkin genel dağılımı Tablo 4'te görmek mümkündür. Buna göre 12 ayda incelenen haberlerde, en çok "bilgi verme" $(\% 25,5)$ ve "tedbir-önlemuyarı" (\%24,3) çerçevelerinin kullanıldığı sonucuna varılmıștır. İncelenen haberlerde ise en az kullanılan çerçevenin "ekonomik sonuçlar-destek-dayanışma" $(\% 5,5)$ olduğu anlaşılmıştır. 
Tablo 4: Çerçevelerin Genel Dağılımı

\begin{tabular}{l|c|c}
\hline & n & $\mathbf{\%}$ \\
\hline Ekonomik sonuçlar-destek-dayanışma & 39 & 5,5 \\
İnsan ilgisi & 43 & 6,0 \\
Ahlak/etik & 53 & 7,4 \\
Siyasileștirme-eleștiri & 77 & 10,8 \\
Korku & 67 & 9,4 \\
Umut & 80 & 11,2 \\
Tedbir-önlem-uyarı & 174 & 24,3 \\
Bilgi verme & 182 & 25,5 \\
\hline
\end{tabular}

Bu bulguların yanı sıra araştırmada, kategoriler arasındaki ilişkiler de incelenmiştir. İlk olarak, gazetelerde salgınla ilgili haberlerin varlığı ve haber çerçeveleri kategorileri arasındaki ilişkiler Tablo 5 'te sunulmuştur. Gazeteler ile ilgili haberin bulunma durumu arasında istatistiksel anlamlı ilişki bulunmaktadır $(\mathrm{p}<0,05)$. İlgili haber bulunan gazete çoğunluk olarak Hürriyet gazetesidir $(\% 45,1)$. Sözcü gazetesinde ise konuyla ilgili haberlerin bulunmama oranı daha yüksektir $(\% 40,9)$.

Gazeteler ile haber çerçevesi arasında da istatistiksel anlamlı ilişki bulunmaktadır $(\mathrm{p}<0,05)$. "İnsan ilgisi" $(\% 46,5)$, "ekonomik sonuçlar-destek-dayanışma" $(\% 66,7)$ haber çerçeveleri daha çok Sabah gazetesinde bulunmaktadır. "Siyasileştirme-eleştiri" haber çerçevesinin tamamı Sözcü gazetesindedir $(\% 100,0)$. Bu bulgu, gazetenin politik konumu ile ilgili bir bulgu olarak gözlemlenmiștir. "Bilgi verme" $(\% 59,9)$, "ahlak/etik" $(\% 56,6)$, "tedbir-önlem-uyarı" $(\% 53,4)$, "korku” $(\% 50,7)$, "umut" $(\% 45,0)$ haber çerçevelerinin ise daha çok Hürriyet gazetesinde olduğu tespit edilmiştir (Tablo 5).

Tablo 5: Gazeteler ile Salgın Haberlerinin Varlığı ve Haber Çerçevelerinin İlişkisi

\begin{tabular}{|c|c|c|c|c|c|c|c|c|c|c|}
\hline & & \multicolumn{2}{|c|}{ Hürriyet } & \multicolumn{2}{|c|}{ Sabah } & \multicolumn{2}{|c|}{ Sözcü } & \multirow{2}{*}{ Ki-kare $\left(\chi^{2}\right)$} & \multirow{2}{*}{$\mathbf{p}$} & \multirow{2}{*}{ Phi } \\
\hline & & $\mathbf{n}$ & \%Satır & $\mathbf{n}$ & \%Satır & $\mathbf{n}$ & \%Satır & & & \\
\hline \multirow{2}{*}{$\begin{array}{l}\text { Salgın } \\
\text { ile ilgili } \\
\text { haber }\end{array}$} & Var & 322 & 45,1 & 205 & 28,6 & 188 & 26,3 & \multirow[b]{2}{*}{58,798} & \multirow[b]{2}{*}{$0,000 *$} & \multirow[b]{2}{*}{0,221} \\
\hline & Yok & 117 & 23,9 & 172 & 35,2 & 200 & 40,9 & & & \\
\hline \multirow{8}{*}{ Çerçeve } & İnsan ilgisi & 10 & 23,3 & 20 & 46,5 & 13 & 30,2 & \multirow{8}{*}{324,109} & \multirow{8}{*}{$0,000 *$} & \multirow{8}{*}{0,673} \\
\hline & $\begin{array}{l}\text { Ekonomik sonuçlar-destek- } \\
\text { dayanışma }\end{array}$ & 10 & 25,6 & 26 & 66,7 & 3 & 7,7 & & & \\
\hline & Ahlak/etik & 30 & 56,6 & 3 & 5,7 & 20 & 37,7 & & & \\
\hline & Siyasileștirme-eleștiri & 0 & 0,0 & 0 & 0,0 & 77 & 100,0 & & & \\
\hline & Korku & 34 & 50,7 & 11 & 16,4 & 22 & 32,8 & & & \\
\hline & Umut & 36 & 45,0 & 34 & 42,5 & 10 & 12,5 & & & \\
\hline & Tedbir-önlem-uyarı & 93 & 53,4 & 57 & 32,8 & 24 & 13,8 & & & \\
\hline & Bilgi verme & 109 & 59,9 & 54 & 29,7 & 19 & 10,4 & & & \\
\hline
\end{tabular}

\section{${ }^{*} \mathrm{p}<0,05$}

Tablo 6'da da görülebileceği gibi, haber çerçeveleri ile aylık periyotlar arasındaki ilişki incelendiğinde ise, çerçeveler ile periyotlar arasında istatistiksel anlamlı ilişki olduğu bulunmuştur $(\mathrm{p}<0,05)$.

Salgının ilk üç ayında daha çok "ekonomik sonuçlar-destek-dayanışma" (\%56,4), "tedbirönlem-uyarı" (\%50,0), "siyasileștirme-eleștiri” $(\% 42,9)$, "insan ilgisi" $(\% 34,9)$ çerçeveleri kullanılmıştır. "Ahlak/etik" haberleri çoğunlukla $(\% 39,6)$ normalleşme, tatil sürecinde bulunmaktadır. "Korku" (\%41,8), "umut" (\%41,3), "bilgi verme" (\%59,2) haber çerçeveleri ise daha çok kapanma, aşılamaya geçiş döneminde bulunmaktadır. Tablo 6'da haber çerçeveleri ile aylık periyotlar arasındaki ilişki detaylı bir biçimde görülmektedir. 
Tablo 6: Haber Çerçeveleri ile Aylık Periyotlar Arasındaki İlişki

\begin{tabular}{|c|c|c|c|c|c|c|c|c|c|c|c|c|}
\hline & & \multicolumn{2}{|c|}{$\begin{array}{c}\text { Salginda } \\
\text { ilk } 3 \text { ay }\end{array}$} & \multicolumn{2}{|c|}{$\begin{array}{c}\text { Normalleşme, } \\
\text { tatil süreci }\end{array}$} & \multicolumn{2}{|c|}{$\begin{array}{l}\text { Sonbahar } \\
\text { önlemleri }\end{array}$} & \multicolumn{2}{|c|}{$\begin{array}{l}\text { Kapanma, } \\
\text { aşılama }\end{array}$} & \multirow[t]{2}{*}{ Ki-kare $\left(\chi^{2}\right)$} & \multirow{2}{*}{$\mathbf{p}$} & \multirow[t]{2}{*}{ Phi } \\
\hline & & $\mathbf{n}$ & \%Satır & $\mathbf{n}$ & \%Satır & $\mathbf{n}$ & $\%$ Satır & $\mathbf{n}$ & $\%$ Satır & & & \\
\hline \multirow{8}{*}{ Çerçeve } & İnsan ilgisi & 15 & 34,9 & 3 & 7,0 & 13 & 30,2 & 12 & 27,9 & \multirow{8}{*}{174,713} & \multirow{8}{*}{$0,000 *$} & \multirow{8}{*}{0,494} \\
\hline & $\begin{array}{l}\text { Ekonomik } \\
\text { sonuçlar } \\
\text { destek } \\
\text { dayanışma }\end{array}$ & 22 & 56,4 & 7 & 17,9 & 1 & 2,6 & 9 & 23,1 & & & \\
\hline & Ahlak/etik & 9 & 17,0 & 21 & 39,6 & 16 & 30,2 & 7 & 13,2 & & & \\
\hline & $\begin{array}{l}\text { Siyasileștirme- } \\
\text { eleștiri }\end{array}$ & 33 & 42,9 & 12 & 15,6 & 16 & 20,8 & 16 & 20,8 & & & \\
\hline & Korku & 13 & 19,4 & 8 & 11,9 & 18 & 26,9 & 28 & 41,8 & & & \\
\hline & Umut & 26 & 32,5 & 1 & 1,3 & 20 & 25,0 & 33 & 41,3 & & & \\
\hline & $\begin{array}{l}\text { Tedbir-önlem- } \\
\text { uyarı }\end{array}$ & 87 & 50,0 & 23 & 13,2 & 38 & 21,8 & 26 & 14,9 & & & \\
\hline & Bilgi verme & 27 & 14,8 & 20 & 11,0 & 27 & 14,8 & 108 & 59,3 & & & \\
\hline
\end{tabular}

${ }^{*} p<0,05$

Tablo 7, gazeteler ile ilgili haberin tüm zaman dilimlerinde ayrı ayrı bulunma durumları arasındaki ilişkiyi göstermektedir ve buna göre gazeteler ile ilgili haberin tüm zaman dilimlerinde ayrı ayrı bulunma durumları arasında istatistiksel anlamlı ilişki bulunmuştur $(\mathrm{p}<0,05)$.

Tablo 7: Periyodlara Göre Gazeteler ile İlgili Haberin Bulunma Durumunun İlişkisi

\begin{tabular}{|c|c|c|c|c|c|c|c|c|c|c|}
\hline \multirow{2}{*}{ Haber tarihi (periyodik) } & \multirow{2}{*}{ Haber } & \multicolumn{2}{|c|}{ Hürriyet } & \multicolumn{2}{|c|}{ Sabah } & \multicolumn{2}{|c|}{ Sözcü } & \multirow{2}{*}{ Ki-kare $\left(\chi^{2}\right)$} & \multirow{2}{*}{$\mathbf{p}$} & \multirow{2}{*}{ Phi } \\
\hline & & $\mathbf{n}$ & \%Sütun & $\mathbf{n}$ & \%Sütun & $\mathbf{n}$ & \%Sütun & & & \\
\hline \multirow{2}{*}{ Salgında ilk 3 ay } & Var & 97 & 90,7 & 73 & 81,1 & 62 & 68,9 & \multirow{2}{*}{14,955} & \multirow{2}{*}{$0,001 *$} & \multirow{2}{*}{0,228} \\
\hline & Yok & 10 & 9,3 & 17 & 18,9 & 28 & 31,1 & & & \\
\hline \multirow{2}{*}{ Normalleşme, tatil süreci } & Var & 45 & 47,4 & 18 & 20,0 & 32 & 34,4 & \multirow{2}{*}{15,392} & \multirow{2}{*}{$0,000 *$} & \multirow{2}{*}{0,235} \\
\hline & Yok & 50 & 52,6 & 72 & 80,0 & 61 & 65,6 & & & \\
\hline \multirow{2}{*}{ Sonbahar önlemleri } & Var & 68 & 64,8 & 45 & 45,9 & 36 & 37,1 & \multirow{2}{*}{16,236} & \multirow{2}{*}{$0,000 *$} & \multirow{2}{*}{0,233} \\
\hline & Yok & 37 & 35,2 & 53 & 54,1 & 61 & 62,9 & & & \\
\hline \multirow{2}{*}{ Kapanma, aşılama } & Var & 112 & 84,8 & 68 & 69,4 & 58 & 53,7 & \multirow{2}{*}{27,727} & \multirow{2}{*}{$0,000 *$} & \multirow{2}{*}{0,286} \\
\hline & Yok & 20 & 15,2 & 30 & 30,6 & 50 & 46,3 & & & \\
\hline
\end{tabular}

*p<0,05

Tüm zaman dilimlerinde, ilgili haberin ilgili kısımda bulunma oranı Hürriyet gazetesinde daha yüksektir. Gazeteler kendi içinde değerlendirildiğinde ise, her üç gazetede de "salgında ilk üç ay" ve "kapanma/aşılama-aşı çalışmaları" dönemlerinde daha çok haber bulunduğu sonucuna erişilmiştir.

Son olarak, haber çerçevelerinin farklı periyodlarda bulunma oranlarının gazetelere göre dağılımı incelenmiş ve Tablo 8'de detaylı olarak sunulmuştur. Her satır için en yüksek yüzdeye sahip çerçeve tablonun daha rahat okunması açısından işaretlenerek görselleștirme yapılmıştır. 
Tablo 8: Haber Çerçevelerinin Farklı Periyotlarda Bulunma Oranlarının Gazetelere Göre Dağılımı

\begin{tabular}{|c|c|c|c|c|c|c|c|}
\hline \multirow{2}{*}{$\begin{array}{l}\text { Haber tarihi } \\
\text { (periyodik) }\end{array}$} & \multirow{2}{*}{ Çerçeve } & \multicolumn{2}{|c|}{ Hürriyet } & \multicolumn{2}{|c|}{ Sabah } & \multicolumn{2}{|c|}{ Sözcü } \\
\hline & & $\mathbf{n}$ & \%Satır & $\mathbf{n}$ & \%Satır & $\mathbf{n}$ & \%Satır \\
\hline \multirow{8}{*}{ Salgında ilk 3 ay } & İnsan ilgisi & 7 & 46,7 & 6 & 40,0 & 2 & 13,3 \\
\hline & Ekonomik sonuçlar-destek-dayanışma & 6 & 27,3 & 15 & 68,2 & 1 & 4,5 \\
\hline & Ahlak/etik & 5 & 55,6 & 0 & 0,0 & 4 & 44,4 \\
\hline & Siyasileştirme-eleștiri & 0 & 0,0 & 0 & 0,0 & 33 & 100,0 \\
\hline & Korku & 8 & 61,5 & 1 & 7,7 & 4 & 30,8 \\
\hline & Umut & 10 & 38,5 & 13 & 50,0 & 3 & 11,5 \\
\hline & Tedbir-önlem-uyarı & 45 & 51,7 & 30 & 34,5 & 12 & 13,8 \\
\hline & Bilgi verme & 16 & 59,3 & 8 & 29,6 & 3 & 11,1 \\
\hline \multirow{8}{*}{$\begin{array}{l}\text { Normalleşme, tatil } \\
\text { süreci }\end{array}$} & İnsan ilgisi & 0 & 0,0 & 0 & 0,0 & 3 & 100,0 \\
\hline & Ekonomik sonuçlar-destek-dayanışma & 1 & 14,3 & 5 & 71,4 & 1 & 14,3 \\
\hline & Ahlak/etik & 10 & 47,6 & 1 & 4,8 & 10 & 47,6 \\
\hline & Siyasileştirme-eleștiri & 0 & 0,0 & 0 & 0,0 & 12 & 100,0 \\
\hline & Korku & 5 & 62,5 & 1 & 12,5 & 2 & 25,0 \\
\hline & Umut & 0 & 0,0 & 0 & 0,0 & 1 & 100,0 \\
\hline & Tedbir-önlem-uyarı & 14 & 60,9 & 7 & 30,4 & 2 & 8,7 \\
\hline & Bilgi verme & 15 & 75,0 & 4 & 20,0 & 1 & 5,0 \\
\hline \multirow{8}{*}{ Sonbahar önlemleri } & İnsan ilgisi & 1 & 7,7 & 7 & 53,8 & 5 & 38,5 \\
\hline & Ekonomik sonuçlar-destek-dayanışma & 0 & 0,0 & 1 & 100,0 & 0 & 0,0 \\
\hline & Ahlak/etik & 12 & 75,0 & 2 & 12,5 & 2 & 12,5 \\
\hline & Siyasileştirme-eleștiri & 0 & 0,0 & 0 & 0,0 & 16 & 100,0 \\
\hline & Korku & 8 & 44,4 & 5 & 27,8 & 5 & 27,8 \\
\hline & Umut & 11 & 55,0 & 8 & 40,0 & 1 & 5,0 \\
\hline & Tedbir-önlem-uyarı & 17 & 44,7 & 15 & 39,5 & 6 & 15,8 \\
\hline & Bilgi verme & 19 & 70,4 & 7 & 25,9 & 1 & 3,7 \\
\hline \multirow{8}{*}{$\begin{array}{l}\text { Kapanma, aşılama - } \\
\text { aşı çalışmaları }\end{array}$} & İnsan ilgisi & 2 & 16,7 & 7 & 58,3 & 3 & 25,0 \\
\hline & Ekonomik sonuçlar-destek-dayanışma & 3 & 33,3 & 5 & 55,6 & 1 & 11,1 \\
\hline & Ahlak/etik & 3 & 42,9 & 0 & 0,0 & 4 & 57,1 \\
\hline & Siyasileştirme-eleştiri & 0 & 0,0 & 0 & 0,0 & 16 & 100,0 \\
\hline & Korku & 13 & 46,4 & 4 & 14,3 & 11 & 39,3 \\
\hline & Umut & 15 & 45,5 & 13 & 39,4 & 5 & 15,2 \\
\hline & Tedbir-önlem-uyarı & 17 & 65,4 & 5 & 19,2 & 4 & 15,4 \\
\hline & Bilgi verme & 59 & 54,6 & 35 & 32,4 & 14 & 13,0 \\
\hline
\end{tabular}

Tablo 8'de görülebileceği ve daha önce de bulgulandığı gibi haberlerin periyodik olarak dönemi fark etmeksizin her dönemde Sözcü gazetesinde "siyasileștirme-eleștiri" çerçevesine yer verildiği anlaşılmaktadır. Gazeteler arasında bir inceleme yapıldığında Hürriyet gazetesinin çerçeveler bazında genel olarak daha yüksek yüzdelere sahip olduğu görülmektedir. Sabah gazetesinde dikkat çeken bir önemli bulgu ise "ekonomik sonuçlardestek-dayanışma" çerçevesine dâhil olan haberlerin, her dönemde en yüksek yüzdeye sahip oluşudur.

\section{Sonuç}

Kriz dönemleri ve özellikle günümüzde küresel olarak deneyimlendiği gibi salgınlar, bilgi akışının ve bilgi ihtiyacının yoğun olduğu dönemlerdir. Bir yılı aşkın süredir devam eden Covid-19 salgınıyla ilgili gazete haberlerinin, çerçeveleme perspektifinden incelenmesine dayanan ve salgının seyriyle birlikte haberlerde kullanılan çerçevelerin nasıl değiştiğini görmeyi amaçlayan çalışmada elde edilen sonuçlar kısaca özetlendiğinde, salgının ilk üç ayında haberlerin yoğun olduğu, yaz aylarıyla birlikte haberlerde ciddi oranda düşüş yaşandığı, sonbaharın gelmesiyle birlikte haberler artarken kapanmayla birlikte yıl 
sonunda haberlerde yine ciddi artış olduğu görülmüştür. Bu doğrultuda haberlerde en çok "bilgi verme" ve "tedbir-önlem-uyarı" çerçevelerinin kullanıldığı anlaşılmıştır. Öte yandan yapılan ilişki analizleri sonucunda, gazeteler ile ilgili haberin birinci sayfada bulunma durumu arasında, gazeteler ile haber çerçeveleri arasında ve son olarak çerçeveler ile salgının üçer aylık periyotları arasında istatistiksel anlamlı ilişki bulunduğu tespit edilmiştir.

Araştırma sonucunda elde edilen bulgular ile literatürde yer alan diğer araştırma sonuçları karşılaştırıldığında birbirini destekleyen ve tamamlayan bulguların olduğu görülmektedir. Sungur ve diğerleri (2020) tarafından, hem yerli hem de yabancı yüksek tiraja sahip internet gazetelerinde yer alan Koronavirüs haberlerinin içerik analizi ile incelendiği çalışmada "sağlık haberlerinin konusuna göre dağılımında ise en çok sayıda haberin 'koruyucu önlem' kategorisinde” yer aldığı tespit edilmiştir. Mevcut çalışmada ise bahsedildiği gibi benzer şekilde en çok kullanılan haber çerçevelerinin ilkinin "bilgi verme", ikincisinin ise "tedbir-önlem-uyarı" olduğu sonucuna erişilmiștir. Öte yandan bu iki çerçevenin kullanım yüzdelerinin birbirine çok yakın olduğu da görülmüştür. Buna göre Covid-19 döneminde krizin yönetilmesi bağlamında alınan pek çok tedbirin ve önlemin haberlere de yansıdığını söylemek mümkündür. Krizin kontrol altına alınabilmesi amacıyla yürütülen tüm çalışmalar, haber içeriklerine de yansımıștır. 1-31 Ekim tarihlerinde The Sun ve Hürriyet gazetelerinin çevrimiçi haberlerinin incelendiği bir diğer çalışmaya göre ise, Hürriyet gazetesinde salgın hastalık temalı haberlerde en çok "hayati risk faktörleri" konulu haberler, ikinci sırada ise "eylem" konulu haberler yer almaktadır (Cılızoğlu vd., 2021, 215). Cılızoğlu ve diğerleri (2021) tarafından yürütülen bu çalışmada "yetkili kurum ve kişilerin hastalıkla ilgili olarak almış oldukları veya alacakları önlemler, çözüm önerileri ve stratejiler konulu haberler" olarak tanımlanan "eylem" kategorisi mevcut çalışmadaki "tedbir-önlem-uyarı" kategorisiyle örtüşmektedir ve bu bulgu, kısmi de olsa araştırmanın sonuçlarını destekler niteliktedir.

Salgının bir yıllık seyri ve haberler çerçeveleri ile haber sayıları arasındaki ilişkiye bakıldığında araştırmada, salgının resmi olarak Türkiye' deki başlangıcı gibi görülebilecek Mart ve Nisan aylarında haber sayılarının yakın olduğu ve Aralık ayından sonra en çok haberin Mart ve Nisan aylarında olduğu tespit edilmiştir. Araştırma sonuçlarına göre ise en az haberin Temmuz ayında olduğu sonucuna varılmıştır. Elde edilen bu bulgu, Yılmaz Altuntaş'ın (2021) çalışmasında yapmış olduğu vurguyla da paralellik göstermektedir. Yılmaz Altuntaş (2021, 184), Mart 2020 tarihinden itibaren Covid-19 haberlerinin niceliksel ve etkileşimsel oranlarında artış olduğunu ancak "normalleşme" dönemine denk gelen Haziran ayında haberlerde "nispi bir azalma görülürken, etkileşim oranlarında önemli düşüşler saptandığını” belirtmiştir.

Çalışmada dikkat çeken bir sonuç, tüm "siyasileştirme-eleştiri" çerçevesi haberlerinin Sözcü gazetesinde yer almasıdır. Bu durum gazeteler ile haber çerçeveleri arasındaki ilişkinin, yayın organlarının temsil ettikleri düşünceyle siyasal ve politik duruşla ilgili olduğunu da göstermektedir. Çerçevenin, bir konunun belirli bir bağlamda sunumu olduğunu ve bu sunumla birlikte dolaylı olarak bir görüşü aktarmanın da amaçlandığını söylemek mümkündür. Buna göre gazetelerin ideolojik konumlarının kullanılan çerçeveleri de etkilediğini varsaymak mümkündür. Araştırma kapsamında dikkat çeken bu bulgu Seyhan, Zararsız ve Ayaşlıoğlu'nun (2021) çalışmasıyla da benzerlik göstermektedir. Pandeminin politikleștirilmesine odaklanan ve pandemi sürecinde gazete haberlerinin ideolojik yanlılıklarını incelemeyi amaçlayan çalışmaya göre; gazetelerde Covid-19 ile ilgili haberler "sahiplik, içerik üretimi ve dil ve ifade kullanımı gibi farklı perspektiflerde politik konumlanış” nedeniyle önemli ölçüde 
farklılaşmaktadırlar (Seyhan vd., 2021). Benzer bir sonuca Kılıç'ın (2021) çalışmasında da ulaşılmıştır. Kılıç $(2021,317)$ çalışmasında, gazetelerin ideolojik duruşlarının, gazetelere göre çerçevelerin kullanımında etkili olduğu sonucuna varmıştır. Literatürde yer alan bu bulgular ışığında, mevcut araștırmada Sözcü gazetesine ilişkin elde edilen bu bulgu daha da anlașılır olmaktadır.

Tüm bu bulgular ışığında sonuç olarak, gazeteler arasında haberleri ele alış ve kullanılan çerçeveler bağlamında farklılıklar olduğu, bu farklılıkların salgının bir yıllık dönemlerine göre de ortaya çıktığı, salgının seyriyle birlikte haberlerde de değişimler gözlemlendiği ve salgının seyrinin haberlere de doğrudan yansıdığını söylemek mümkündür. Öte yandan çalışmanın başında da belirtildiği gibi her çalışma bir sınırlılık içermektedir ve literatüre kendi sınırlılıkları bağlamında bir katkı sunmaktadır. Bu çalışma bir yıllık süredeki tüm haberleri kapsamadığı gibi, salgının günümüzde devam eden seyri, araştırmacıları bu konuda daha detaylı araştırmalar yapmanın da önünü açmaktadır.

\section{Notlar}

1. Hastalıkları Kontrol ve Önleme Merkezleri

2. İncelenen toplam gazete sayısıyla ilgili şu noktaya dikkat çekmek gerekmektedir. Tarama ilk vakanın ortaya çıktığı 11 Mart 2020 tarihinde başladığı için Mart ayının ilk 10 günü araştırma kapsamına alınmamıştır. Öte yandan araştırmada gazetenin birinci sayfalarına "gazeteoku.com" sayfasından erişim sağlanmış ancak bazı incelenen tarih aralığında gazetelerin bazı günlerine erişilememiştir. Örneğin 17 Şubat 2021 Sabah ve Sözcü gazeteleri, 24-25-26 Mayıs 2020 ile 3-4 Temmuz 2020 tarihlerinde her üç gazetenin de birinci sayfalarına erişim sağlanamamıștır. 12 aya göre bakıldığında toplamdaki sayı farklılığının nedeni bu şekilde açıklanabilir.

3. Birinci sayfada birden fazla haber olduğunda çoklu kodlama yapılmıștır. Her bir haber ayrı ayrı kodlanmıştır. 


\section{Kaynakça}

Baden, C. "Framing the News". The Handbook Of Journalism Studies. Ed. Karin WahlJorgensen - Thomas Hanitzsch, 229-245, New York, NY: Routledge, 2019.

Berger, Peter L. - Luckmann, Thomas. Gerçekliğin Sosyal İş̧ası Bir Bilgi Sosyolojisi Incelemesi. İstanbul: Paradigma, 2008.

Choi, Minhee - McKeever, Brooke W. "News framing of avian flu: Media advocacy and response to a public health crisis". Newspaper Research Journal, 40/4 (2019), 451466.

Cılızoğlu, Gamze Yetkin - Dondurucu, Zeynep Benan - Çetinkaya, Aysel. "The Sun ve Hürriyet Gazetelerinde Covid-19 Konulu Haberlerin Kültürel Farklılıklar Bağlamında Değerlendirilmesi". Covid-19 Sürecinde İletişimin Değişen Yüzü. Ed. Gülsüm Çalışır ve Ersin Diker, 198-232, Konya: Eğitim Yayınevi, 2021.

Cottle, Simon. Global Crisis Reporting Journalism in the Global Age. Berkshire, England: McGraw-Hill, Open University Press, 2009.

Çaplı, Bülent - Taş, Oğuzhan. "Kriz Haberciliği” Televizyon Haberciliğinde Etik. Ed. Bülent Çaplı - Hakan Tuncel, 237-250, Ankara: Fersa, 2010.

Çınarlı, İnci. Sağlık İletişimi ve Medya. Ankara: Nobel, 2008.

Damstra, Alyt - Vliegenthart, Rens. "(Un)covering the Economic Crisis? Over-time and inter-media differences in salience and framing". Journalism Studies, 19/7 (2018), 983-1003.

de Vries, Michiel S. "Framing Crises: Response Patterns to Explosions in Fireworks Factories". Administration \& Society, 36/5 (2004), 594-614.

Dursun, Çiler. "Haberde 'Gerçekliğin İnşa Edilmesi' Ne Demektir?”. Haber Hakikat ve Íktidar İlişkisi. Ed. Çiler Dursun, 37-65. Ankara: Elips Yayınları, 2004.

Durur, Elif Küçük. "İnşacı Yaklaşım İçinde Çerçeveleme Kuramı ve Haberin Çerçevelenişi”. Atatürk Illetişim Dergisi, 2 (2011), 21-31.

Ekström, Joakim. "The phi-coefficient, the tetrachoric correlation coefficient, and the Pearson-Yule Debate". UCLA: Department of Statistics, UCLA. 2011, Erişim 12 Mayıs 2021. https://escholarship.org/uc/item/7qp4604r

Entman, Robert M. - Matthes, Jörg - Pellicano, Lynn. "Nature, Sources, and Effects of News Framing". The Handbook OfJournalism Studies. Ed. Karin Wahl-Jorgensen - Thomas Hanitzsch, 175-190. New York, NY: Routledge, 2009.

Entman, Robert M. "Framing: Toward Clarification of a Fractured Paradigm". Journal of Communication 43/4 (1993), 51-58.

Fearn-Banks, Kathleen. Crisis Communications: A Casebook Approach. New York, NY: Routledge, 2017.

Fetzer, James H. "Information: Does it Have To Be True?". Minds and Machines, 14 (2004), 223-229.

Girgin, Atilla. Yazılı Basında Haber ve Habercilik "Etik"i. Ankara: İnkılap, 2000.

Goffman, Erving. Frame analysis An Essay on the Organization of Experience. Boston: Northeastern University Press, 1986. 
Gülnar, Birol - Acar, Nihal. "Salgın Hastalıklar Döneminde Sosyal Medyanın Korku Algısında Meydana Getirdiği Değişimin İncelenmesi: Covid-19". Nitel Sosyal Bilimler, 3/1 (2021), 140-163.

Hallahan, Kirk. "Seven Models of Framing: Implications for Public Relations". Journal of Public Relations Research, 11/3 (1999), 205-242.

Hayes, Andrew F. - Krippendorff, Klaus. "Answering the call for a standard reliability measure for coding data". Communication methods and measures, 1/1 (2007), 7789.

Heath, Robert L. "Introduction Crisis Communication: Defining the Beast and Demarginalizing Key Publics". The Handbook of Crisis Communication. Ed W. Timothy Coombs- Sherry J. Holladay, 1-13, UK: Wiley-Blackwell, 2010.

Holladay, Sherry J. "Are They Practicing What We Are Preaching? An Investigation of Crisis Communication Strategies in the Media Coverage of Chemical Accidents". The Handbook of Crisis Communication. Ed W. Timothy Coombs- Sherry J. Holladay, 159-180. UK: Wiley-Blackwell, 2010.

Huck, Schuyler W. Reading Statistics and Research. Boston: Pearson, 2012.

Iannarino, Nicholas. T. - Veil, Shari R. - Cotton, III Alfred J. "Bringing Home the Crisis: How US Evening News Framed the 2011 Japan Nuclear Crisis". Journal of Contingencies and Crisis Management, 23/3 (2015), 169-181.

Kazaz, Mete - Pala, Saibe - Kazaz, Arzu. "Covid-19 Aşı Haberlerinde Çerçeveleme: Haber Sitelerinde Aşı Haberlerinin Sunumu”, INIF E- Dergi, 6/1 (2021), 343-361.

Kılıç, Seyfi. "Türk Yazılı Basınında Covid-19 Haberlerinin Çerçevelenmesi”. Akdeniz Üniversitesi İletişim Fakültesi Dergisi, 35 (2021), 317-337.

Kim, Young. "Understanding publics' perception and behaviors in crisis communication: Effects of crisis news framing and publics' acquisition, selection, and transmission of information in crisis situations". Journal of Public Relations Research, 28/1 (2016), 35-50.

Knight, Myra Gregory. "Getting past the impasse: Framing as a tool for public relations". Public Relations Review, 25/3 (1999), 381-398.

Krippendorff, Klaus. Content Analysis : An Introduction to Its Methodology. Thousand Oaks, California: Sage, 2004.

Kutlu, Asuman. "Framing the Crisis: An Analysis of Turkish News Coverage of COVID-19", Journal of Current Researches on Social Sciences, 10/2 (2020), 305-314.

Larsson, Larsåke. "Crisis and Learning". The Handbook of Crisis Communication. Ed W. Timothy Coombs- Sherry J. Holladay, 713-718, UK: Wiley-Blackwell, 2010.

Liu, Brooke Fisher - Kim, Sora. "How organizations framed the 2009 H1N1 pandemic via social and traditional media: Implications for US health communicators". Public Relations Review, 37/3 (2011), 233-244.

Ma, Ringo. "Media, crisis, and SARS: An introduction". Asian Journal of Communication, 15/3 (2005), 241-246.

Madsar, Serhat. "Yeni Şafak, Sözcü, Yeni Akit ve Cumhuriyet Gazetelerinin Covid-19 Haberlerinin Çerçeveleme Kuramı Bağlamında İncelenmesi”. Geçmişten Günümüze 
İletişim Araştırmaları I. Ed. Hasan Çiftçi, 3-27. Ankara: İksad Publishing House, 2020.

Mason, Alicia M. "The Impact of Media Frames and Treatment Responsibility within the Situational Crisis Communication Theory Framework". Corporate Reputation Review, 17/1 (2014), 78-90.

Mutua, Sylvia Ndanu - Ong'ong'a, Daniel Oloo. “Online News Media Framing of COVID-19 Pandemic: Probing the Initial Phases of the Disease Outbreak in International Media". European Journal of Interactive Multimedia and Education, 1/2 (2020), e02006.

Narin, Fatma Bilge. Küresel Terör Saldırlarına Yönelik Haberlerin Türk Basınında Çerçevelenişi. Ankara: Ankara Üniversitesi, Sosyal Bilimler Enstitüsü, Yüksek Lisans Tezi, 2008.

Neuman, W. Lawrence. Social Research Methods: Qualitative and Quantitative Approaches. Essex, England: Pearson, 2014.

Nguyen, An - Catalan, Daniel M. "Digital Mis/Disinformation and Public Engagment with Health and Science Controversies: Fresh Perspectives from Covid-19". Media and Communication, 8/2 (2020), 323-328.

Nwakpu, E. Sanita - Ezema, V. Okwudilichukwu - Ogbodo, J. Nwakpoke. "Nigeria media framing of coronavirus pandemic and audience response". Health promotion perspectives, 10/3 (2020), 192-199.

Ogbodo, J. Nwakpoke - Onwe, E. Chike - Chukwu, Joseph - Nwasum, C. Jude - Nwakpu, E. Sanita - Nwankwo, S. Ugochukwu - Nwamini, Samuel - Elem, Stephen - Ogbaeja, N. Iroabuchi (2020). "Communicating health crisis: a content analysis of global media framing of COVID-19”. Health Promotion Perspectives, 10/3 (2020), 257-269.

Özarslan, Hüseyin - Güran, M. Salih. "İletişim Araştırmalarında Çerçeveleme Paradigması: Son Döneme Ait Bir İnceleme”. Selçuk İletişim, 8/4 (2015), 32-48.

PAHO (Pan American Health Organization). "Understanding The Infodemic and Misinformation in the Fight Against Covid-19". 2020, Erişim 12 Mayıs 2021. https://iris.paho.org/bitstream/handle/10665.2/52052/Factsheetinfodemic_eng.pdf?sequence $=14 \&$ isAllowed $=y$

Pan, Po-Lin - Meng, Juan. "Media Frames Across Stages of Health Crisis: A Crisis Management Approach to News Coverage of Flu Pandemic". Journal of Contingencies and Crisis Management, 24/2 (2016), 95-106.

Pieri, Elisa. "Media Framing and the Threat of Global Pandemics: The Ebola Crisis in UK Media and Policy Response". Sociological Research Online, 24/1 (2019), 73-92.

Pira, Aylin - Sohodol, Çisil. Kriz Yönetimi Halkla İlişkiler Açısından Bir Değerlendirme. İstanbul: İletişim Yayınları, 2015.

Poirier, William - Ouellet, Catherine - Rancourt, Marc-Antoine - Béchard, Justine Dufresne, Yannick. "(Un)Covering the COVID-19 Pandemic: Framing Analysis of the Crisis in Canada". Canadian Journal of Political Science, 53/2 (2020), 365-371.

Porta, Miquel. A Dictionary of Epidemiology. New York, NY: Oxford University Press, 2014.

Pereira, P. Silveira - Silveira, A. Silva - Pereira, Antonio. "Disinformation and Conspiracy Theories in the Age of COVID-19". Frontiers in Sociology, 5 : 560681 (2020), 1-5. 
Reese, Stephen D. "Prologue-Framing Public Life: A Bridging Model for Media Research". Framing Public Life Perspectives on Media and Our Understanding of the Social World. Ed. Stephen D. Reese vd., 7-32. Mahwah, New Jersey: Lawrence Erlbaum Associates, 2001.

Riegert, Kristina - Olsson, Eva-Karin. "The Importance Of Ritual In Crisis Journalism”. Journalism Practice, 1/2 (2007), 143-158.

Saraç, D. Çeliker. “Domuz Gribi Haberlerinde Çerçeveleme: Hürriyet Gazetesi Örneği””. Global Media Journal TR Edition, 8/16 (2018), 161-185.

Sarığlu, Elif Başak - Turan, Erkan "COVID-19 ile ilgili haberlerde bilginin yeniden üretilmesi sürecinin infodemik açıdan analizi”. Turkish Studies, 15/6 (2020), 819837.

Schultz, Friederike - Utz, Sonja - Göritz, Anja. "Is the medium the message? Perceptions of and reactions to crisis communication via twitter, blogs and traditional media". Public Relations Review, 37/1 (2011), 20-27.

Semetko, Holli A. - Valkenburg, Patti M. "Framing European politics: A content analysis of press and television news". Journal of Communication, 50/2 (2000), 93-109.

Seyhan, Ahmet Selman - Zararsız, Ömer Faruk - Ayaşlığlu, Emrah. "Pandeminin Politikleștirilmesi ve Söylem: Cumhuriyet ve Sabah Gazeteleri Örneğinde Koronavirüs Haberleri Üzerine Bir Analiz". Akdeniz Üniversitesi İletişim Fakültesi Dergisi, 35 (2021), 17-37.

Seyidov, Ilgar. "Türk Basınında Sunulan Kırım Krizi Haberlerinin Çerçeveleme Kuramı Bağlamında İncelenmesi”. Akdeniz İletişim Dergisi, 22 (2014), 60-73.

Sungur, Sevda - Yücel, Ezgi - Metintaş, Selma - Önsüz, Muhammed Fatih. "Yüksek Tiraj Yapan Yerli ve Yabancı İnternet Gazetelerinin Koronavirüs Hastalığı ile İlgili Haber İçeriklerinin İncelenmesi". ESTÜDAM Halk Sağlığı Dergisi, 5 (2020), (COVID-19 Özel Sayısı), 47-60.

Tabachnick, Barbara G. - Fidell, Linda S. Çok Değișkenli İstatistiklerin Kullanımı. Ankara: Nobel, 2015.

Tagliabue, Fabio - Galassi, Luca - Mariani, Pierpaolo. "The "Pandemic" of Disinformation in COVID-19". SN Comprehensive Clinical Medicine, 2/9 (2020), 1287-1289.

Wibhisono, I. G. L. A. Kharisma. "Framing Analysis of the Kompas' COVID-19 Coverage: January 2020 Edition". Jurnal ASPIKOM, 5/2 (2020), 219-231.

Wimmer, Roger D. - Dominick, Joseph R. Mass Media Research An Introduction. Boston, USA: Wadsworth, Cengage Learning, 2014.

Wright, Kevin B. - Sparks, Lisa - O’Hair, H. Dan. Health Communication in the 21st Century. Malden, MA: Wiley-Blackwell, 2013.

Yılmaz Altuntaş, Elgiz. (2021). "Covid-19 Pandemisine İlişkin Yayınlanan Online Haberlerin Konu Türü ve Etkileşim Oranı Temelli Çerçeveleme Analiz”. Pandemi Neoliberalizm Medya. Ed. Yasemin G. İnceoğlu ve Savaş Çoban, 183-209, İstanbul: Ayrintl, 2021. 